\title{
TECHNOGENIC CHANGE OF THE GEOLOGICAL ENVIRONMENT OF URBAN AREAS (BY THE EXAMPLE OF IRKUTSK TOWN)
}

\author{
Kadetova A. V. ${ }^{1}$, Rybchenko A. A. ${ }^{1}$, and Trzhcinsky Yu. B. ${ }^{1}$ \\ 'Institute of the Earth's Crust Academy of Sciences Siberian Branch, Laboratory of engineering \\ geology and geoecology, Lermontov Street 128,664033 Irkutsk, Russia, kadetova@crust.irk.ru, \\ rybchenk@crust.irk.ru,trzhcin@crust.irk.ru
}

\begin{abstract}
The paper discusses engineering-geological problems of urban areas, among which are geohazards like flooding, suffosion subsidence, erosion, and gravitation. It is the concern of the research to do both natural and industrial effect analyses. A detailed historical-geological evaluation has been made of urban spatial development as one of the main geological environment modification factors.
\end{abstract}

Key words: Urban areas, exogenous geological processes.

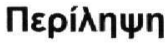

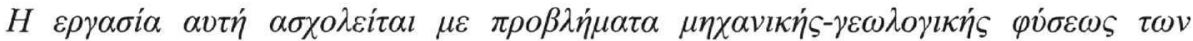

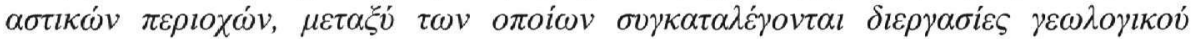

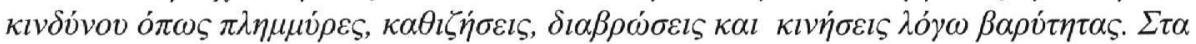

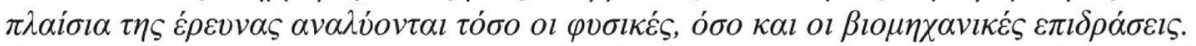

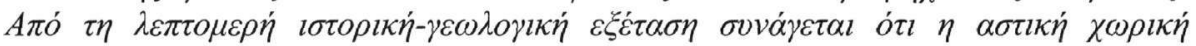

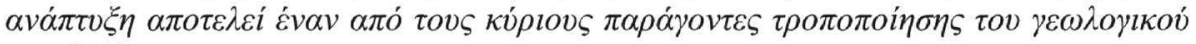
$\pi \varepsilon \rho \imath \beta \dot{\lambda} \lambda \lambda$ ovто५.

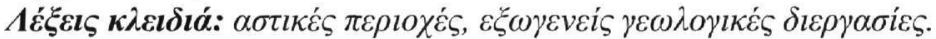

\section{Introduction}

Urban areas are complex natural-technical systems of relatively confined interaction between geological environment components and technogenic factors. Technogenic effects radically altered the geological environment of Irkutsk town over more than three-hundred-year history of its development. It resulted in the extension of urban space affected by exogenous geological processes in particular and in the change of some geological environment components as a whole. The natural-technogenic interactions provide a complex spatial and temporal picture of naturaltechnical system condition for urban area, the understanding of which is an essential prerequisite to the prediction of ecological-geodynamic state of the agglomeration, and foreseeing and mitigation of geological hazards. These problems can be solved through the study of engineeringgeodynamic evolution of Irkutsk town that is a vital issue in development of new sites and in redevelopment. 


\section{Materials and Methods}

The basis for this paper is the evidence obtained as a result of natural researches done on the area of Irkutsk town in 2000-2006 wherein the processes of suffosion, erosion and gravitation were revealed and analyzed. The analysis of the above-mentioned processes made it possible to determine natural and technogenic effects controlling their development. Besides, the chronicle analysis has given us an insight into the change of geological environment of the town for all history of its development. The theoretical basis for solving problems is the data of research done on the engineering-geological conditions of Irkutsk in the last few decades. Among the materials used were the results of integrated geological, hydrogeological and engineering-geological survey at a scale of 1:50000, and published and library materials.

In an effort to analyze hazardous geological processes on the area of Irkutsk town under the influence of some of the factors, the geoinformation system (GIS) has been found as a convenient in solving engineering-geological problems. The database-referred electronic fiber map of natural conditions of the area and infrastructure facilities was produced with the use of MapInfo Professional software version 6.5. The foundation of the GIS is large-scale thematic maps of different years of publication: historic (XVII-XX centuries) and recent topography plan of Irkutsk, a map of seismic zoning etc. All available information was systematized in GIS databases. The fiber mapping of engineering-geological conditions, geological environment and technogenic load is as follows: geological environmental conditions of the town based on the geomorphological map of the area (the fiber database includes the information on lithology, cover thickness, genesis of rocks, depth of groundwater occurrence, processes typical of the area). Some fiber maps are geological processes at different stages of development of the town (from the beginning to the present day). The technogenic loading conditions are presented by the development plan of the town, the database of which includes basic parameters of buildings.

In comparing of a number of maps and analyzing industrial effects, the geological environment of Irkutsk town has been estimated at different stages of its development and the factors of modification of engineering-geological conditions have been correlated.

\section{Investigated area}

Irkutsk town founded in 1652 is now a large industrial-administrative center of the East Siberia, the population of which is more than 550 thousand people. The town is not a compact populated area as the Angara River and its tributaries, Irkut and Ushakovka Rivers, dissociate some of its parts. The Angara River separates the town into left-bank and right-bank sides linked together by two bridges and Irkutsk hydroelectric dam.

\section{Engineering-geological conditions}

The area of Irkutsk town and its immediate surroundings lies within hilly erosion-denudation terrain represented by the Jurassic and Quaternary deposits. Most of the town is located on the second bottom and terraces of the Angara, Irkut, Ushakovka, Kaya, Topka and other rivers composed of alluvium 5-15 m thick, overlain by slope detritus. New housing complexes are on the adjacent slopes and divides.

The river valley slopes as a whole are gentle, and they are very gentle between the Angara and Ushakovka Rivers within the city. Most widespread are subhorizontal (to $2^{0}$ ) and gently sloping (to $10^{0}$ ) surfaces occupying up to $80 \%$ of the townsite. The maximum elevation difference of divides and valley bottoms is ranging from 100 to $170 \mathrm{~m}$ 's, so that geomorphological conditions are favorable to erosion.

The geological structure is characterized by a widespread occurrence of coal-bearing formations and about $30-\mathrm{m}$ thick sedimentary cover of diverse genesis (alluvial, deluvial, proluvial, and 
eluvial) of the Quaternary. The rocks of Jurassic formation are composed by badly weatherworn, seamy sandstones, aleurolites and argillites alternating with coal horizons of different thickness and clays. Structure of this type is an essential prerequisite to the propagation of landslides of various types (Trzhtsinsky et al. 2005).

A peculiarity of this area is that the loess soils are common almost everywhere. According to the data reported by Ryashenko and Akulova (1997), the loess soils cover the Angara River terraces and are shaped as islands on divides and slopes. They represent the accumulations of the third and fourth terraces on the right bank of the Angara River (the area of the Right Bank district including Solnechny housing complex), those of the third and forth terraces on the left bank of it (waterfront of the Sverdlovsky district), and divides (a part of Yubileiny housing complex, $3^{\text {rd }}$ hydroelectric dam settlement, and Sinyushina Gora). Their thickness is typically from 1-4 to $15-20 \mathrm{~m}$. The existing soil conditions are often characterized by underconsolidation (dry unit weight is 1.44-1.65 $\mathrm{g} / \mathrm{cm}^{3}$, porosity ratio is $\left.0.89-1.13\right)$ and low water saturation ratio $(0.2-0.4)$ that makes them favorable to subsidence, soaking and washing (Akulova 2000). The soils having the abovementioned properties have a natural suffosion subsidence and erosion potential. The now erosion forms are progressing rapidly on the slopes, primarily on deluvial and loess soils. Active gullies are confined to different elements of old erosion forms - creek valleys filled with proluvial soils to $8 \mathrm{~m}$ in thickness.

Prior to building the central part of Irkutsk was a boggy area with soft soils and peat bogs (Romanov 1994, Pezhemsky and Krotov 1911). Alternate moistening and drying of these soils resulted in washing of soil fractions, cavitation, soil heaving, and a sharp decrease of soil bearing capacity. The Angara and Irkut Rivers overflowed during spring flood and winter ice formation and inundated the near-bank areas.

By this means natural conditions of the townsite were initially favorable to erosion and suffosion subsidence advancing and to flooding and inundation. But the extent to which they are affected by natural and technogenic effects changed with an urban development and load increase.

\section{Historical-geological analysis of technogenic factors}

The geological environment of the Irkutsk townsite radically altered in more than three hundredyear history of its development under anthropogenic and technogenic effects.

Historical-chronological survey of the urban ecosystem has allowed us to recognize five main stages in the urban development, each of them characterized by a considerable increase of technogenic effect. At the first and second stages (1652-1879) the technological effect on the geological environment of the town was minimum and produced minor change in the natural geodynamic setting. This effect was in deforestation, minimum technological intervention in building improvement (bog drainage), and originally timber housing. The concept of effect on the geological environment of the town varied but slightly for a long time, the affected area was only extended.

The third stage (1879-1903) is characterized by the beginning of primarily stone housing. At this stage of urban development the human activity is aimed at land improving and overcoming some of the bad effects. For example, in an effort to improve building conditions, modification of hydrological conditions is continued involving the bog drainage. All technological interventions at this stage of urban development were of local character, however they caused both positive and negative changes.

At the forth stage (1903-1950) most of the changes in geological environment of the town were related to railway building and working start that gave rise to extension of the townsite and involved quite another man-made effects associated with plate-laying. An example of hazard slope phenomenon in the railway-affected area is the old-railway sliding in summer 1948. Apart from 
high moisture content of deluvial sandy loams and loamss and a high degree of slope, the sliding was induced for the most part by dynamic loads at train movements (Lomtadze 1977).

Besides, in the early $20^{\text {th }}$ century work was begun on the improving of the townsite. In 1903-1905 the first public water supply utility was laid in the main streets of Irkutsk. From this point onward the underground utilities have been extended that creates additional subsidence and suffosion conditions (Romanov 1994). In the 1940s work was begun on the asphalting that results mainly in the change of evaporation and runoff and thus in that of hydrologic balance. At this stage more complex engineering produces change in the town geosystem, some components of which (hydrological conditions, hydrologic balance, and soils) changed under technogenic effects.

The fifth stage (from 1950 to the present day) of the development of Irkutsk town is confined to putting the Irkutsk hydroelectric station into operation in the middle 1950s and reservoir filling. The construction of dam gave rise to the reservoir in the Upper Angara River having caused changes of hydrological regime and hydrologic balance of the area. In the whole field of history of its development the town was frequently inundated during breakup, after rainfalls, and as a result of ice gorge with the ice formation. At this stage the situation changed after the Angara River regulation by the reservoir. On the other hand, after the hydrologic dam construction the ground water rise through bypass filtration in the right-bank side of the town caused suffosion subsidence activity (Shenkman and Shenkman 1997). Besides, the advent of artificially impounded bodies gave rise to abrasion. This process makes itself evident in the near-shore area of Solnechny housing complex (Ovchinnikov et al. 1999).

At this stage of development of the town geosystem the activation of natural and natural-industrial processes and purely technogenic processes characterize the engineering-geological conditions.

\section{Results and discussion}

The analysis of exogenous geological processes has been made. It has been found that those associated with the action of surface and underground waters (suffosion subsidence, groundwater discharge, bogging, flooding, and inundation) in the central part of the town, bottomland plots and on the surface of the first terrace of Angara River occur naturally under the minimum technological effect. A bayou lake that occupied the present-day area of Kirov Square in the XVII century was dewatered into the Angara River (Irkutsk chronicle, 2003). The area currently built up with the central market and shopping complex, boggy in the XVIII century, was also drained by backfill (Romanov, 1994). Upon dewatering and draining the above-mentioned areas, the flooding and bogging resumed there at seasonal showers. The groundwater discharge and associated soil subsidence were common in the old course of the Gryaznukha River that occupied the present-day area of Uritsky, Karl Marx and Pyatoi Armii Streets (Irkutsk chronicle, 2003). Throughout the whole development of the town natural factors played a decisive role in the processes, and the minimum human interventions at the first stage of the town development did not exert much effect on the engineering-geological conditions. But the effects that were induced at the fourth and fifth stages caused changes in the geological environmental conditions and become predominant in the above-mentioned processes.

As of now, most of the area of Irkutsk is covered by underground water-bearing pipeline network. Underconsoloidation of soils after the backfill results with time in soil shrinkage and its surface or internal erosion. The formation of underground cavities and leaking are responsible for suffosion along the pipelines. The observed suffosion subsidence processes are confined just to the area of influence of the underground water-bearing pipeline systems. In response to the rupture of $200-\mathrm{m}$ long pipeline section in Universitetsky housing complex 10 large suffosion forms up to $2.8 \mathrm{~m}$ wide and $1.0 \mathrm{~m}$ deep occurred in one spring month (Fig. 1). Sinkholes and subsidence showed up there in loessal loams, for which a skeletal-aggregate microstructure $(26.9 \%)$ and a low free fine-clay fraction index $(15.4 \%)$ have been determined. The loams are carbonaceous, plastic $(7.1 \%)$, 

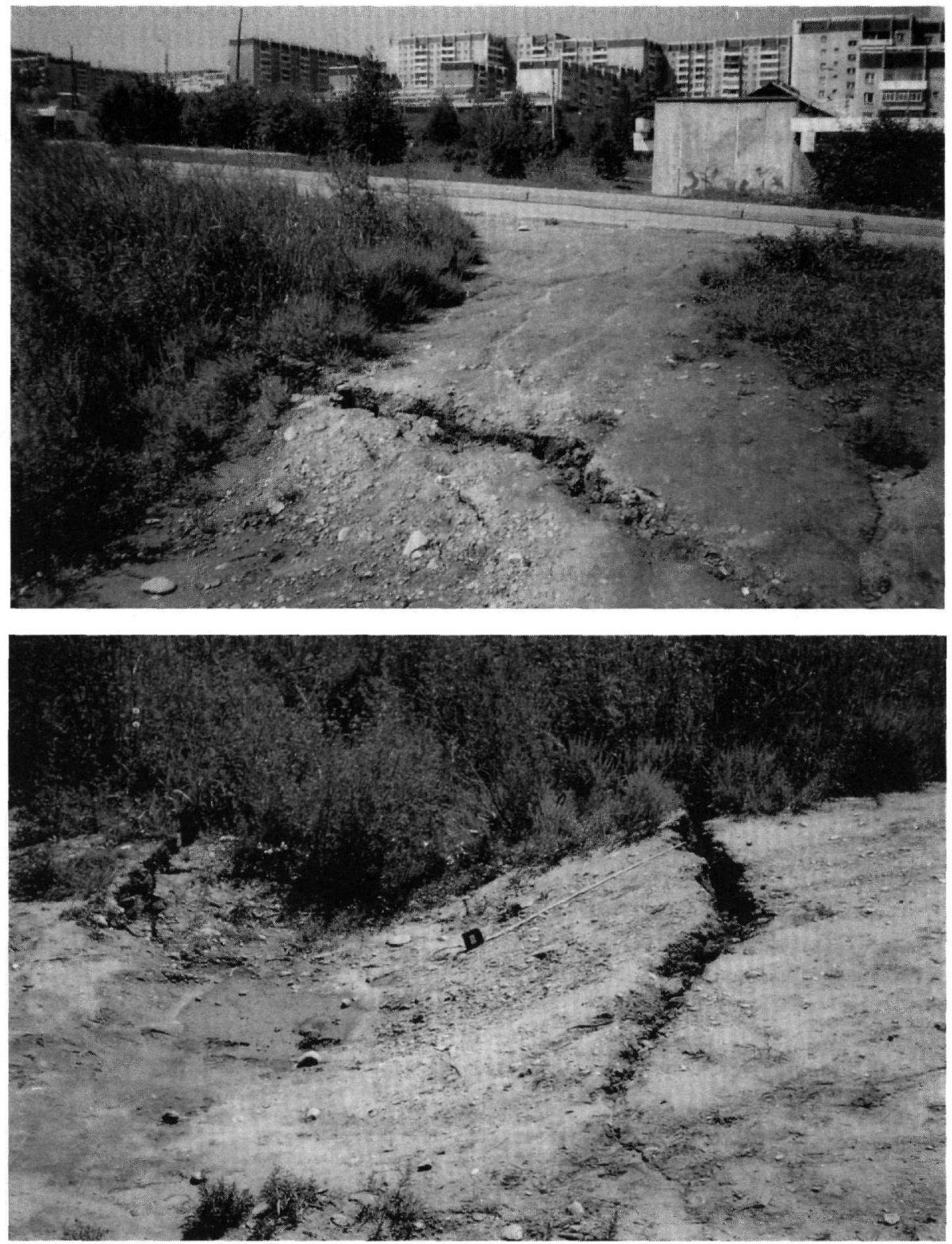

\section{Figure 1 - The suffosion-subsidence processes above the underground sewer systems}

middle-density $\left(1.72 \mathrm{~g} / \mathrm{cm}^{3}\right)$, and have a reduced strength in the water-saturated conditions (cohesion is $0.25 \mathrm{kgc} / \mathrm{cm}^{2}$, internal friction angle is $31^{\circ}$ ).

The suffosion subsidence phenomena observed on the area of Irkutsk town have been mapped and based with regard to their parameters. For the segments in which they are most common according to the data on the map of geological processes the suffosion subsidence factor has been calculated with the formula: $K_{\text {пр }}=\Sigma f_{\text {пр }} / F$, where $F$ is an overall area of an estimate unit and $f_{\text {пр }}$ is a total area of the process. The affected area of Universitetsky and Pervomaisky housing complexes adds up to $11 \%$. The obtained coefficient is significant, as these were not suffosion-prone sites to development and improvement. The area of Sinyushina Gora is nine percent affected with suffosion. It is an inherited process there. The map of engineering-geological zoning of Irkutsk 
town shows hummock-and-hollow topography for the area of Sinyushina Gora that may be associated with soil subsidence. The current subsidence of soil intensified by leakage from pipelines is of purely technogenic nature. Soil subsidence is also inherited on the area of the central part of the town that is now 14 percent affected with suffosion. In the XIX and early XX centuries the main streets of the town were affected by subsidence and sinkholes in various sizes and shapes that was favored by a high groundwater level on fore-boggy areas. At present both inherited and recent suffosion subsidence is production-induced and affect large areas.

Inundation, inherited for Irkutsk town, specifically for its central part, is now progressing under technological effects. Among these are unsatisfactory condition of the underground water-bearing pipelines (losses from water supply, water carriage and heating systems); groundwater dam in the bypass filtration zone in the Irkutsk hydrologic dam shoulders (Shenkman and Shenkman 1997); travel of water through a dam above permitted standard; groundwater dam at deep-piled foundation; building in fluvial plains, natural drainage disturbance; construction of railway and highway systems changing the surface runoff character (Burdukovsky 1977); asphalting of most of the area and thus insufficient evaporative power.

Erosion was common on gently sloping divides and loamy terrace slopes. According to the chronicles (Romanov 1994, Pezhemsky and Krotov 1911) and the data presented by L.A. Sirotkin, various processes for erosion like sheet flooding, washing and gullying, and undercutting were observed on the areas of Lisikha, hydrologic dam settlements, Studenchesky gorodok, and on leftbank side of the Angara River to land improvement. Nowadays extensive erosion on the above areas has come to a halt part way and has been brought part way under control owing to the land improvement and planning. The current erosion affects for the most part undeveloped lands and recreation zones, and the terrace slopes composed of loose deposits. The main evolution and activation factors for erosion are scalping, man-made relief, and technological losses from pipelines. Some gully heads grow in result of suffosion subsidence.

In the spring-summer period of 2001 a gully to $1.5 \mathrm{~m}$ deep, $4 \mathrm{~m}$ wide and $15 \mathrm{~m}$ long was induced on the slope of the third terrace above flood plain (Universitetsky housing complex). Most of it is occupied by grassland vegetation with some grouped trees. The entire area was at one time a recreation zone unaffected by erosion. But the autodrome construction associated with scalping and land formation gave rise to erosion conditions. The deciding factor contributing to the formation of the gully was the surface runoff concentration on the slope-crossing trace, the side fence of which in its turn interfered with the downslope runoff. Because of this, the water flew down the road speeding up at the curve and acquiring a high destructive power that is responsible for the gully (Fig. 2).

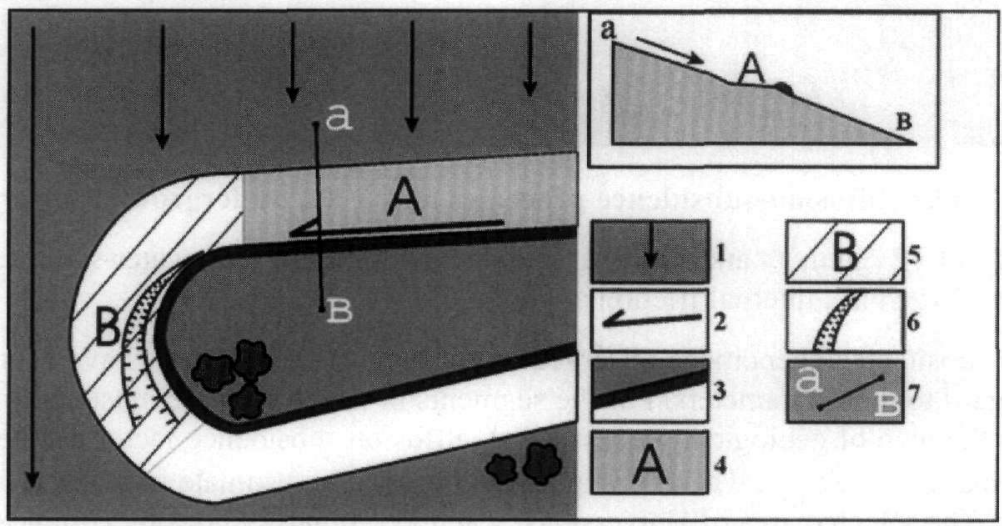

Figure 2 - Pattern of the formation of technogenic ravine (district Universitetskiy) 
1 - the direction of the surface drain of the water; 2 - direction of the road incline; 3 - the roadside ground wall, which impedes the flow of the water; 4 - the zone of the concentration of the surface drain; 5 - the zone of the maximum speed of the aqueous flow; 6 - the ravine; 7 - the profile

Early in the development of the town, earth sliding affected steep unterraced slopes composed of the Jurassic sandstones. Confined to river valley slopes, the sliding activity is due river erosion, high groundwater level, and jointing. Earth sliding on the area of Irkutsk town is both inherited and technogenic. The Ershovsky landslide is an example. In accordance with the data of Maslov (1933), on the left bank of the Angara River above Irkutsk there were three old parts of sliding, almost inundated in reservoir impoundings. Undercutting the upper slope for construction of water intake unbalanced one of these parts that might jeopardize the construction, and the toe structure was banked then to stop the slide (Trzhtsinsky et al. 2005). Inherited also are the landslides nearby "Angara" resort and on the right bank of the Irkut River. Both old inactive and recent active sliding occurs nearby the "Angara" resort. The sliding propagates in solid rocks. Geologically both parts of the slope are composed the Jurassic sandstones alternating with argillites and aleurolites. The Kaya valley slope is characterized by a stepped profile formed by old sliding. The sliding blocks that are 15-50 m long and 5-10 m wide have defined slide circus, decollement wall and crest of the main scarp, and yet all sliding features are smoothed and grass-covered. Dust loess-like sandy loams and light loams 1-1.5 m thick overlie the solid rocks.

The Irkut valley slope below the Kaya River mouth is steep with an angle of slanted surface 20$40^{\circ}$, complicated by sliding features, the turf is in many parts split by gaping joints, observed are step structure, hummocks, mud streams and other sliding microforms. Among these are ruptures to several meters in length, often grass-uncovered, sliding trenches to $1 \mathrm{~m}$ in width with solid rocks and decollement walls exposed. A characteristic of the landslides is "drunk" forest with bent trunks inclined in different directions (Rybchenko 2001).

The slide of another type is that in the wall of the brickworks quarry in Novo-Lenino (Fig. 3). In the middle 1980s the loess-like loams and sandy loames with interlayered clays and sands slid along the watered clayey horizon as a result of surface water concentration above the clayey level due to the water encroachment with the garbage dumping upwards the slope (Fig. 4). The debris accumulation slowed down the soil evaporation. The slid masses moved right up to some of the brickworks facilities and affected the high-voltage network support.

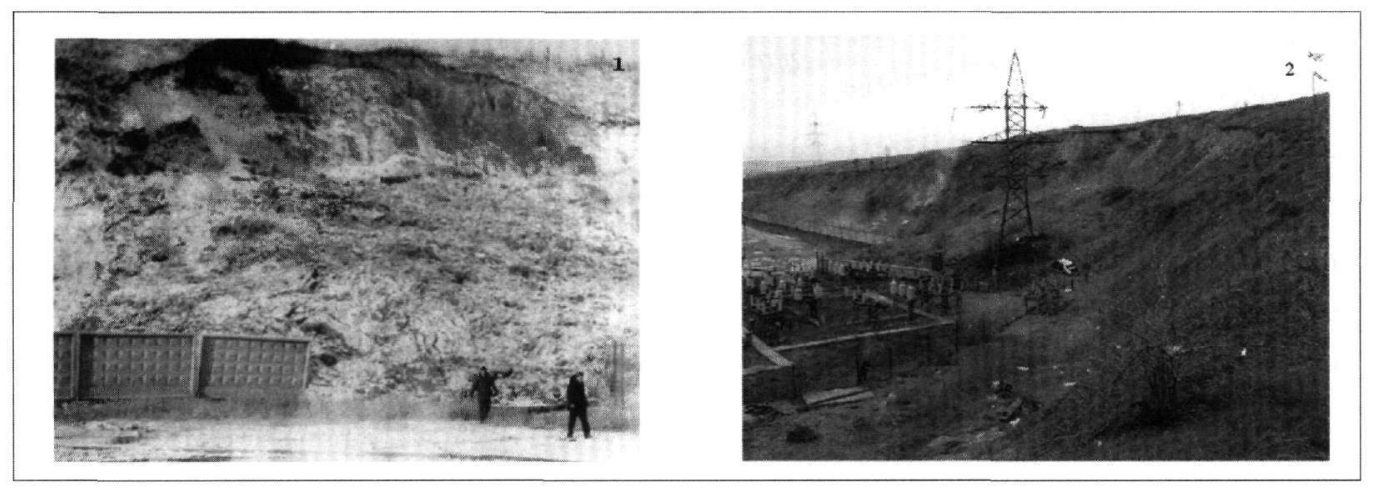

Figure 3 - Landslide on the slope of the quarry (in the area of the brick plant in the district of Novolenino) (1 - 1985 year; 2 - 2004 year) 


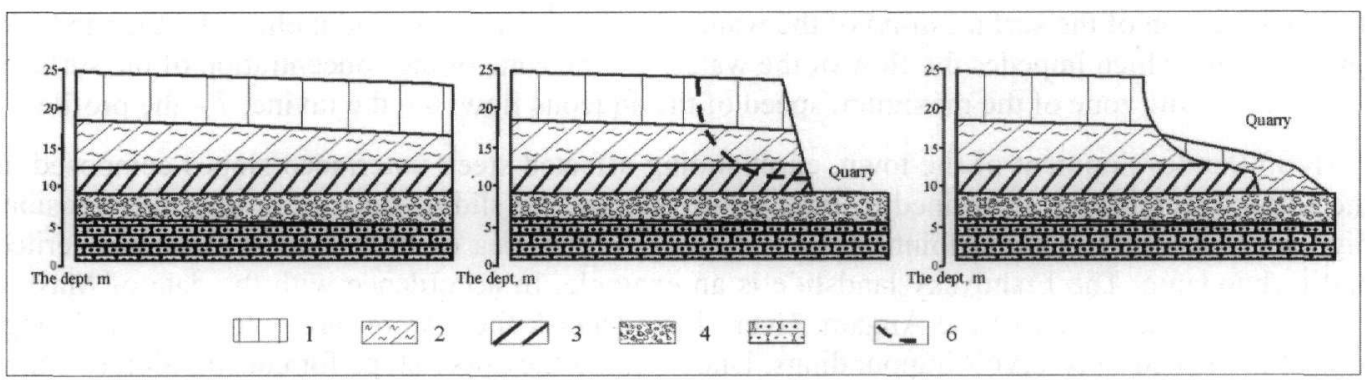

Figure 4 - The scheme of the landslide development (in the area of the brick plant in the district of Novolenino)

1 - loessial loams (horizon II); 2 - loams and sand dust with the interlayers of clays and sand (horizon I); 3 - clays and the loams of the floodland facies; 4 - gravel and pebbles with the sand; 5 - sandstones; 6 - boundary of the slip surface of the landslide

Hence the engineering radically altered the town geosystem. Natural conditions and constant increasing in technogenic loads gave rise to a new natural-technogenic system. As this takes place, natural effects are decreasing, some of the processes initiated by these effects came to a halt, and some other processes are currently initiated by technogenic effects or new technogenic medium.

\section{Acknowledgments}

The work has been done under financial support of RFBR (Project No. 06-05-64186).

\section{References}

Akulova, V.V., 2000. Assessment of seismic hazard for loess soils of Pribaikalye. Reading from Sergeev. Vol. 2. Reports for annual session of the Research Council RAS on the problems of geoecology, engineering geology and hydrogeology. Moscow, March 23-24, 2000. GEOS, Moscow, 11-14. (in Russian)

Burdukovsky, V.A., 1997. Influence of the travel of water through the Irkutsk hydrologic dam above permitted standard on inundation of the Irkutsk townsite. In Problems of estimating and predicting stability of the geological environment of Irkutsk town, Collection of scientific papers. - Irkutsk, 162-164. (in Russian)

Irkutsk chronicle 1661-1940, 2003. Yu.P. Kolmakov, chronographer, author of introduction and notes, Ottisk, Irkutsk, 848pp. (in Russian)

Lomtadze, V.D., 1977. Engineering geology. Engineering geodynamics, Nedra, Leningrad, 479pp. (in Russian)

Maslov, V., 1933. On morphology of old landslides on the bank of the Angara River near Irkutsk. Acad. V.L. Komarov (ed.), Proceedings of the State Geographical society, vol. LXV, 1-6. Tech. Theor. Publ. House, Science sector of the People's Commissariat of Education, Leningrad, 140-146. (in Russian)

Ovchinnikov, G.I., Pavlov, S.Kh., and Trzhtsinsky, Yu.B., 1999. Change of the geological environment in the Angara-Yenisei reservoir-affected areas, Nauka, Novosibirsk, 254pp. (in Russian)

Pezhemsky, P.I., and Krotov, V.A., 1911. Irkutsk chronicle. - Steam typography of I.P. Kazantsev, Irkutsk, 418 pp. (in Russian)

Romanov, N.S., 1994. Chronicle of Irkutsk town over 1902-1924, East-Sib. Publ. House, Irkutsk, 555pp. (in Russian) 
Rybchenko, A.A., 2001. Sliding slope of the Irkut and Kaya valley nearby "Angara" resort of Irkutsk town, XIX All-Russian Youth Conference. Structure of lithosphere and geodynamics, Irkutsk, 209-210. (in Russian)

Ryashenko, T.G., and Akulova, V.V., 1997. Problems of loess science of the East Siberia and adjacent areas (an experience of regional analysis). In Loess soil subsidence: research, design and building (report for plenary meeting of the Int. Sci. Conf.), Barnaul, 26-45.(in Russian)

Shenkman, B.M., and Shenkman, I.B., 1997. Hydrogeological condition evolution on the Bolshoy Irkutsk area. In R.M. Lobatskaya (ed.), Problems of estimating and predicting stability of the geological environment of Irkutsk town, Irkutsk, 39-43. (in Russian)

Trzhtsinsky, Yu.B., Kozyreva, E.A., and Verkhozin, I.I., 2005. Engineering-geological features of the Irkutsk amphitheater, Irkutsk Polytechnical.University Press, Irkutsk, 124pp. (in Russian) 